\title{
Conjunctival Melanoma cT1d TNM Finding v8
}

National Cancer Institute

\section{Source}

National Cancer Institute. Conjunctival Melanoma CT1d TNM Finding v8. NCI Thesaurus.

Code C140568.

Conjunctival melanoma with tumor of the bulbar conjunctiva, involving 3 or more quadrants. (from AJCC 8th Ed.) 